\title{
The Failure of the New Macroeconomic Consensus: From Non-Ergodicity to the Efficient Markets Hypothesis and Back Again
}

\author{
Nigel F.B. Allington, John S.L. McCombie and Maureen Pike
}

\begin{abstract}
The subprime crisis raised some fundamental questions about the usefulness of mainstream economics. This paper considers the shortcomings of the New Neoclassical Synthesis and the New Macroeconomic Consensus in analysing the causes and consequences of the crisis. It shows that the major problem was the assumption that the future could be modelled in terms of Knightian risk (as in the rational expectations and efficient markets hypotheses). It is shown that the near collapse of the banking system in the advanced countries was due to a rapid increase in radical uncertainty. Suggestions are made for the future development of financial macroeconomics.
\end{abstract}

Keywords: Sub-prime crisis, ergodicity, risk and uncertainty.

\section{Introduction}

Much has now been written on the 2007 subprime crisis and economists have a fairly good idea as to its proximate causes: namely, problems of securitisation, inadequate credit ratings of the various tranches by the three credit rating agencies and conflicts of interest in the ratings procedure, principal-agent problems in the banking system leading to excessive risk taking, moral hazard (banks 'too big to fail') contagion effects in Europe and elsewhere, global imbalances and the failure of monetary policy. To this must be added the amplifying effects of the large increase in leverage of the banks that had occurred over the last two decades. (See, for example, Blanchard, 2009, Brunnermeier, 2009, Rajan, 2005 and 2010, Roubini and Mihm, 2010). Consequently, this is not examined in any depth. The focus of this paper is on the shortcomings in macroeconomic theory, especially the rational expectations hypothesis (REH) and the efficient markets hypothesis (EMH) that the subprime crisis exposed, far beyond any formal testing could have done. See, for example, Summers (1991) for a jaundiced view of the usefulness of econometrics in altering any economist's weltanschauung.

After the acrimonious debates of the 1980s between the Neo-Keynesians and the New Classical economists over REH and the assumption of market clearing, there seems to have arisen an uneasy truce. This was reflected in the development of the New 
Neoclassical Synthesis based essentially on the New Classical approach complete with rational expectations, but with Neo-Keynesian sticky prices grafted on. This putatively represented the maturing of macroeconomics based on sound microfoundations (Goodfriend, 2004 and 2007). While there were some mainstream dissenters (e.g. Solow, 2008), most macroeconomists, apart from the post-Keynesians, seemed to subscribe to this view. But the subprime crisis changed all this. Blanchflower (2009), a member of the UK monetary policy committee found macroeconomic theory of no use in understanding the crisis or the appropriate policy response, a view also shared by Buiter (2009). Moreover, debates took place about the fundamental foundations of macroeconomics (Krugman, 2009 and Cochrane, 2009) showing that the divisions were as deep as ever.

In this paper, first the development of the New Neoclassical Synthesis (NNS) and the New Macroeconomics Consensus (the latter refers to the applied studies and policy implications, most notably inflation targeting) based on the former are examined. The shortcomings of this approach are then considered in the light of the subprime crisis. In particular, one of the major shortcomings of the NNS, namely that individuals and institutions act in the presence of Knightian uncertainty (in a non-ergodic world) rather than, as assumed by the NNS, being faced by risk given by a well-defined probability distribution. The conclusions look at the methodological way forward, with a discussion of behavioural economics and behavioural finance.

\section{From the Non-Ergodicity of the General Theory to the Ergodicity of the REH and EMH and Back Again}

The Great Depression led to a paradigm shift with the publication of the General Theory of Employment, Interest, and Money (1936) and the development of the "economics of Keynes" displacing "the postulates of the classical economics". The central tenet of the General Theory was the role of inadequate effective demand in accounting for unemployment and not real or money wage rigidity. Of crucial importance was the role of expectations and how individuals responded to the future (most notably in Chapter 12 of the General Theory and in Keynes's [1937] response to his critics). The volatility of capitalist systems both in terms of investment decisions and asset prices depends on how individuals both singly, and collectively, respond to uncertainty. In other words, the economic system is non-ergodic (Davidson, 1982-3). 
However, in the 1940s and 1950s macroeconomics did not follow Keynes's lead and seek a deeper understanding of "conventional expectations", that is to say, expectations driven by conventions. (This only occurred several decades later with the development of behavioural economics.) The blame for this 'wrong turning' can be laid squarely at the door of Hicks as he later conceded (Hicks, 1979) and the development of the IS-LM model where, within a general equilibrium framework, uncertainty disappeared. The grafting on to the IS/LM model of the neoclassical labour market analysis lead as a matter of logic (what elsewhere McCombie and Pike [2010] have termed 'paradigmatic determinism') to involuntary unemployment being determined by real wages being too high. The Lucas critique, the need for microfoundations and 'model consistent' or rational expectations and the assumption of market clearing led to the rise of New Classical economics. Involuntary unemployment was seen as a theoretically meaningless concept (Lucas, 1978).

In this approach, the representative agent is modelled using an intertemporal utility maximising framework. This explains fluctuations in employment, given the individual's expectations of intertemporal exogenous productivity shocks. The role of the rate of interest is to reconcile the intertemporal demand for, and supply of, output. The empirical fact that real wages varied procyclically refuted the neoclassical explanation of real wage rigidity as a cause of unemployment (which implies a countercyclical real wage). Hence, cyclical fluctuations, again as a result of paradigmatic determinism, must be caused by shifts in the demand function for labour due to technological shocks. Thus, the core of this approach is the real business cycle. Even the occurrence of excess capacity is explained as the result of optimising procedures, namely, variations in the intensity with which maintenance is carried out (McCombie, et al., 2010).

The neo-Keynesians had been developing models within the same macroeconomic framework with optimising models based on the representative agent, but had introduced optimal reasons for temporary price stickiness, such as menu costs (Calvo pricing). Given the underlying similarity of the conceptual framework, these insights were eventually incorporated into the real business cycle model, but within an imperfect competition framework and a mark-up pricing policy. Nevertheless, the rigidities were the result of an optimisation process. It is this that gives a role for monetary policy. 
The limitations of the NNS (and its counterpart, the dynamic stochastic general equilibrium (DSGE) models) were well-known even before the subprime crisis (McCombie and Pike, 2010). The use of the representative agent, far from being an innocuous assumption, is the sine qua non of the whole approach. It does not solve the aggregation problem, but merely assumes it way. For example, the aggregate production function does not exist theoretically, even as an approximation (Fisher, 1992) and it cannot be justified in terms of empirical verification and Friedman's instrumentalist approach (Felipe and McCombie, 2005). Kirman (1992) has shown that the preferences of the representative agent can be totally different from those of all the individuals that the agent is supposed to represent. There is also the Sonnenschein-Mantel-Debreu theorem which has serious implications for these models through the existence of multiple equilibria and stability and which have been totally ignored, with one or two notable exceptions (for example Solow, 2008). Chen (2010) adopting a statistical approach shows that, under plausible assumptions, the law of large numbers implies that the relative deviation of macroeconomic indices is between 0.1 and 1 percent. This implies that the number of 'agents' for the US should be between 6,000 and 200,000. Thus, "the observed relative fluctuations are at least 20 times larger than could explained by the microfoundations models in labour or producer models (p. 58)".

The representative agent assumption also rules out any unemployment due to Keynesian demand deficiency and especially arising from coordination failures. The shortcomings of the DSGE also revolve around the necessary assumption of the transversality condition. This condition effectively rules out any consideration of bankruptcy or the existence of risk premia (see Buiter, 2009 and Goodhart, 2010). Given these shortcomings, attempts are now being made within this paradigm to relax these assumptions by introducing risk premia, and explicitly modelling systemic risk. However, it can be legitimately asked, given the other paradigmatic assumptions of the DSGE models, whether this will lead to any greater insights? There is still no need for financial institutions, including banks, or even money in these models (Meyer, 2001). Thus, they cannot theoretically explain the effects of the subprime crisis, which arose directly endogenously from the banking system and an understanding of it requires a detailed contextual knowledge of the institutions (see below). 


\section{The Failure of the Taylor Rule and the New Macroeconomic Consensus}

The implications of the NNS are twofold. First, it gave confidence to policy makers that the economy was self-stabilising and, indirectly, it led to 'light financial regulation' Secondly, it provides a theoretical justification for inflation targeting (Meyer, 2001). The question arises therefore of how useful is the NCM in explaining the causes of the crisis?

The limitations of NCM were also known before the crisis (Arestis, 2009), but were likewise ignored by the central banks. It assumes that the inflation rate to be targeted (core inflation) rises due to excess demand. It therefore excludes any element of costpush inflation and real wage resistance which many have plausibly argued was the major cause of inflation in the early 1970s (McCombie, 2010, pp. 119-123). A further shortcoming is that it excludes any role for increased competition from China and India allowing the advanced countries to keep down costs as an explanation of the Great Moderation. This is notwithstanding the fact that it meant the loss first of blue collar jobs in the US to these countries and ultimately to the loss of white collar jobs (Samuelson, 2004).

Within this framework, the only way the house price bubble can be adequately explained is via lax monetary policy, unless it is treated as an exogenous shock (Fama, 2010). The former is the view of Taylor (2007 and 2009). He finds that over the period 2003-2006 the actual federal funds rate was substantially below the level predicted by the Taylor rule. According to Taylor, low interest rates generated the housing boom. With the housing boom, delinquency rates and foreclosures fell. But with the crash, the last two rose dramatically, triggering the crisis. This implies that defaults are a rational response; "when prices are falling, the incentives to make payments are much less" (Taylor, 2009, p.12). Of course, in these models there is not much scope for involuntary actions, such as households being unable to pay their mortgages.

However, this explanation is not convincing. Taylor justifies the argument by showing that the rapid growth of the number of housing starts, which showed a rapid rise over the period from 2000 to 2006, would not have been so fast if interest rates had been higher. Thus, Taylor (2009) comes to the conclusion that "this extra-easy [interest rate policy] accelerated the housing boom and thereby led to the bust". The policy implication is straightforward - the Federal Reserve should have stuck to the Taylor rule. 
There are a number of problems with this explanation. First, remaining within the NCM framework, Bernanke (2010), drawing on the work of Dokko et al., (2009), points out that the correct measure of inflation to use in the Taylor rule should be the forecast and not the actual rate. When this is used, there is no evidence that interest rates were too low. (Allington et al., [2010] find the same result for the operation of European monetary policy.)

Secondly, the number of housing starts in the US is very small compared with the total housing stock (only 1.73 per cent in 2001). Moreover, while the growth of housing starts was fast over 2001-2006 at 5.16 per cent per annum, the average rate for the previous ten years was still rapid at 4.62 per cent. One would have thought that, if anything, the increased supply of housing would have dampened the rate of increase in house prices, not accelerated it. Furthermore, the evidence suggests that only a small proportion of the rise in house price can be attributed to interest rate policy (Bernanke, 2010, p.13). Vector analysis suggests that the actual federal funds rate was close to the predicted' whereas the increase in house prices was well outside the predicted range. Hence, Bernanke (2010, p.14) concludes "when historical relationships are taken into account, it is difficult to ascribe the house price bubble either to monetary policy or to the broader macroeconomic environment."

Clearly, the cause must lie elsewhere and the evidence is that the house price bubble was determined endogenously and was the result of financial innovation. The explosive growth of securitization of mortgages and particularly subprime mortgages and the move to 'originate and distribute' (with the shifting of the risk burden from the banks to investors) was primarily responsible for the start of the boom. ${ }^{1}$ Evidence for this is provided by Mian and Sufi (2008). Using US county data they first calculate the fraction of mortgage applications that were turned down by banks in 1996. They term this 'latent demand' and find those counties with the higher level of latent demand had the greater growth in mortgages and house prices after 1996. This cannot be attributed to an increase in the overall level of creditworthiness in these counties. In fact, per capita income was falling there. They also find that the rapid increase in the granting of mortgages was associated with securitization. Those areas where the latent demand was eventually

\footnotetext{
${ }^{1}$ Seventy five percent of subprime loans were securitised in 2006 and $20 \%$ of all mortgages were subprime in that year.
} 
satisfied were the ones that subsequently had proportionally the largest number of defaults. In their opinion, which is shared by many others, the proximate cause of the crisis was moral hazard on behalf of the originators (the banks) of the subprime mortgages (see also Rajan, 2005). But there is more to it than this.

\section{The Failure of the Ergodicity Assumption}

The key cause was the failure of credit ratings for asset-backed securities derived using assumptions that assumed ergodicity. One of the central tenets of Keynes's explanation of the instability of the capitalist system is the pervasive influence of Knightian uncertainty (Knight, 1921) and animal spirits on both the investment decision and stock market purchases (see again Chapter 12 of the General Theory and Keynes, 1937).

Risk is a situation where the individual, using past experience, can form a subjective distribution function about a particular process, say stock returns, that is, it reflects the one that actually exists. Thus, it is possible to assign a numerical probability to an event occurring. Because it is necessary to learn about the probability generating function over time, it is a requirement that this does not change; in other words the world must be ergodic. (Stationarity of the data is a necessary, but not sufficient, condition for ergodicity.) Estimates of risk normally are calculated as a function of the standard deviation of returns.

Referring to the stock market, Keynes noted that in a crisis or speculative boom when there is no basis for rational calculations, expectations become "conventional", by which he meant driven by convention. One important convention in the formation of expectations is the belief that the majority have better information than the individual. If all participants were to take this view, then herd behaviour arises leading to a selffulfilling prophecy and either 'irrational exuberance' or investor panic. Yet, because these animal spirits are difficult to model (or else lead to nihilistic conclusions) modern macroeconomics has disregarded these important insights of Knight and Keynes.

Indeed, macroeconomics went to the other extreme with the widespread adoption of REH by both the New Classical and neo-Keynesians in the late 1980s. And although macroeconomics is effectively divorced from the theory of finance, the EMH assumed rational expectations (Fama, 1965). Thus the EMH requires the joint test of the REH and 
the Capital Asset Pricing Model. The REH assumes that the world is ergodic, a concept first given prominence in economics by Samuelson (1969) who utilised the martingale result. Samuelson argued that the assumption of ergodicity was necessary if economics was to be "scientific", but he nevertheless warned against attaching too much importance to his result because "it does not prove that actual competitive markets work well (p.48)". Hence the strong version of the REH assumes any individual (who, to make the assumption coherent, has to be the representative agent) makes use of all available information (past, present and future, public and private as well as assuming that the model is the correct representation of the world) without making systematic errors. This implies that the individual's subjective probability distribution is the same as the 'true', or objective, probability distribution and can be determined from historical data. In other words, the objective density function must not change (Samuelson's 1969 assumption) or if it does, the individual must be able to ascertain the new distribution in some mechanical way (Frydman and Goldberg, 2010). ${ }^{2}$ But individuals clearly cannot perform this mental gymnastics from past data. Given therefore that the future is unknowable, the REH and EMH founders on Hume's "fallacy of induction" principle (1888). More practically, Frydman and Goldberg (2010) argue that the inevitability of structural changes in the probability generating function, occurring over time, empirically undermines the claim that the EMH "is the best tested proposition in all the social sciences" (Cochrane, 2009, p.3). If the probability distribution changes over time, then conventional testing techniques are flawed, even if attempts are made to allow for these changes. Moreover, in the case of the Capital Asset Pricing Model, where it did perform well in the 1960s, later examination of it suggested that the model was, in the words of Fama, "atrocious as an empirical model" (cited by Freedman and Goldberg, 2008, p.17).

Leamer (2010) has argued that non-ergodicity is about three-valued logic. Suppose, he argues, that it can be deduced from a model that there is a particular probability of an event occurring, $p_{l}$ and on that basis a particular decision is taken, say, whether to invest or not. This is an example of Knightian risk. But suppose that an alternative and equally good model gives a probability of, $p_{2}$ this is a "world of Knightian uncertainty in which expected utility maximisation does not produce a decision" (p.39). This assumes, of course, that the distribution over the interval $p_{1}$ to $p_{2}$ is not uniform. Instead, there are

\footnotetext{
${ }^{2}$ See also Hendry and Mizon (2010) for a discussion of the econometric problems that arise when there are unanticipated changes. Because almost no time series is found to be stationary, DSGE models "are intrinsically non-structural and must fail the Lucas critique since their derivation depends upon constant expectations distributions (p.13)".
} 
epistemic probabilities over the intervals. While the decision-making is two-valued logic, either invest or don't, the state of mind is three valued - invest, don't invest, or else "I don't know".

The subprime crisis illuminated the failings of the EMH in a way that no econometric test or a priori reasoning could have done. While the process of securitization was not new, it grew rapidly in the mid-2000s. ${ }^{3}$ But securitization was unreservedly welcomed by the former Federal Reserve Chairman, Greenspan and former Treasury Secretary, Summers in the light of the EMH as yet another financial innovation that would led to the more efficient allocation of capital resources through the diversification of risk ${ }^{4}$ Securitization took an illiquid asset, the flow of payments from subprime mortgages with an assumed probability of default and on this basis constructed a Collateralised Debt Obligation (CDO) that could be sold on to other financial institutions. By dividing the CDOs into tranches, so that the junior tranche bore the first (higher) risk and the senior tranche the least, the latter could be given a credit rating (mostly AAA) which was substantially higher than the rating would have been without that division. Thus investors with different attitudes towards risk could be accommodated. While the junior tranche bore greater risk, it consequently generated a higher return. More sophisticated CDOs were created using the junior tranches to create mezzanine $\mathrm{CDOs}$ and also $\mathrm{CDO}^{2} \mathrm{~s}$ and this led to further AAA rated tranches. ${ }^{5}$ In fact, the number of AAA rated CDOs as a proportion of the total greatly exceeded the number of AAA rated corporate bonds.

The major change was that the banks providing the subprime loans were now engaged in 'originate and distribute' and did not assess the creditworthiness of the individual mortgagees. The risk had been passed on to the investor and was assessed using complex computer algorithms to calculate the likelihood of default. This was based on past data which, it was assumed, followed a Gaussian distribution: one of the crucial assumptions was that past performance was an excellent predictor of future returns. As Coval et al., (2008) have shown, the probabilities on default are extremely sensitive to the exact

\footnotetext{
${ }^{3}$ Securitization of mortgages was partly responsible for a minor credit crunch in 1990 and Bernanke and Lown (1991, p.217) could conceive of no good economic reason for securitization. ${ }^{4}$ During the 1990s Greenspan and Summers actively opposed further regulation of the financial markets. This was on the grounds that self-regulation was perfectly adequate and any regulation would reduce the competitiveness of the US finance industry. Summers had been instrumental in the eventual repeal of the Glass-Steagall Act in 1999.

${ }^{5}$ Mezzanine asset and mortgage-backed securities are mainly backed by BBB or even lower rated mortgage bonds. In 2006 \$200bn of these were issued (with $70 \%$ exposed to subprime bonds) representing $40 \%$ of all CDOs issued that year.
} 
parameters chosen for the model and the procedures crucially did not take account of the potential for systemic failure. Rather securitization was assumed to have removed this problem by diversifying the risk. Indeed Fitch, one of the three major credit ratings agencies, revealed that their ratings were based on the assumption that house prices would increase indefinitely. Asked what would happen if house prices fell by between $1 \%$ or $2 \%$ for any extended period of time, Fitch replied that their models "would break down completely" (cited by Coval et al., 2008).

The details of the subprime crisis are well known. With the collapse of the US housing market, the default rate on subprime mortgagees rose and the current market value of CDOs became uncertain and the level of risk associated with them could not be determined. Wenli et al., (2010) show that changes to the US bankruptcy law in 2005 caused the level of defaults on prime and subprime mortgages to rise, driving house prices down even faster. Consequently, the market for CDOs froze ${ }^{6}$ (violating in the process one of the assumptions the EMH) and the value of all the CDOs plummeted. Those companies such as Lehman Brothers and AIG that had sold Credit Default Swaps (CDSs) acted as insurers against default on CDOs and offered premiums based on a Gaussian distribution assuming the probability of default to be small. ${ }^{7}$ They ignored the probability of a systemic collapse in the value of CDOs (the so-called 'fat tail' problem).

The crisis elicited a mixed response from the authorities with Lehman Brothers forced into bankruptcy and AIG bailed out by the US government because of the perceived systemic risk from its failing. CDOs held by the banks 'off balance sheet', typically in Structured Investment Vehicles, had to be brought back on to the balance sheet. With no 'market maker' to purchase these CDOs and to guarantee a well-organized and orderly resale market, they were virtually worthless under mark-to-market pricing. As a result, the banks' capital base collapsed. As Davidson (2008) pointed out, given the uncertainty over the value of the CDOs and thus the soundness of the banks' capital base, there was a flight to liquidity by the banks. And interbank lending froze given the uncertainty over the ability of the borrowing banks to repay. This had knock-on effects pushing Northern Rock in the UK into bankruptcy: not because it held 'toxic assets', but because it depended on the short-term money market to fund its aggressive expansion strategy. (The government quickly decided to nationalise it.) There was also a simultaneous credit

\footnotetext{
${ }^{6}$ See Davidson (2008) for a discussion of the absence of a market-maker in the subprime crisis.

${ }^{7}$ On that basis they held no capital assets to meet possible 'insurance' claims.
} 
crunch with credit rationed even for seemingly creditworthy firms. ${ }^{8}$ The subsequent recession therefore did not hinge on real wages being too high, but resulted from the liquidity problems of firms which, through the multiplier, led to a severe collapse in Keynesian aggregate demand. (Bernanke and Blinder [1988] incorporate a model of the credit crunch in the standard IS-LM framework.)

Davidson (2008) has convincingly argued that this was not a Minskyian "Ponzi moment", but rather the result of increased uncertainty and the ultimate insolvency of the counterparties. He is in agreement, therefore, with Taylor (2009) who points to the rapid widening of the LIBOR-OIS spread indicating that the cause of the crisis was uncertainty; the inability of the market to value accurately the capital assets of the banks. If this diagnosis is correct, then simply pumping money into the economy (Quantitative Easing version I or II) in an attempt to bring down the spread would prove ineffective. Instead, the banks should be recapitalised so that they can resume their lending activities.

\section{Was the Subprime Crisis a Random Shock?}

It has been argued by Fama (2010) and Lucas (2009) that because few professional economists or financial journalists saw the crisis coming, this is a justification of the EMH! Lucas, for example, wrote "one thing we are not going to have, now or ever, is a set of models that forecast sudden falls in the value of financial assets, like the declines that followed the failure of Lehman Brothers in September 2008. This is nothing new. It has been known for more than 40 years and is one of the main implications of Eugene Fama's 'efficient markets hypothesis' ". As the EMH assumes individuals make use of all the available information, then bubbles and their inevitable collapse have to be treated as unforeseen stochastic shocks. Lucas is surely correct when he claims that policy-makers could not predict the exact timing or the precise severity of the crisis. But the fact is that the endogenous changes through financial innovations in capital markets and the structure of incentives facing traders in the banks were obvious for anyone who had a detailed knowledge of financial institutions to see. The NCM and the DSGE are based on the assumption that the functioning of a complex system like an economy can be adequately described and predicted on the basis of linearised relationships between a few

\footnotetext{
${ }^{8}$ This occurred on a much smaller scale in 1990 in the US as a result of a fall in the banks' holdings of real estate assets which were part of their capital adequacy ratio. See Bernanke and Lown (1991). Monetary policy was assumed to be able to cope with the credit crunch, except where the banks refused to lend (i.e. there is credit rationing) and there was a liquidity trap. Thus the 2007 crisis was a very much more severe rerun of the 1990 credit crunch.
} 
macroeconomic variables..$^{9}$ Hence, if the model abstracts from the actual behaviour of financial institutions, then by definition information about them is irrelevant under REH. And while the timing of the collapse could not be predicted, it is clear that as Rajan (2005), the Chief Economist at the IMF pointed out, there was high probability of a severe banking crisis. The shortcomings of the EMH and its underlying assumptions had also been demonstrated during the collapse of Long-Term Capital Management in 1997, but the lesson had not been learnt. Its collapse also signalled the authorities' disregard for moral hazard.

This complex reality throws into doubt what precisely is meant by the assumption in the REH that agents make use of "all available information". The forgoing analysis makes it clear that the subprime crisis was endogenously determined and that only the timing and its depth were exogenous. In a non-ergodic world, where there is institutional change that is path dependant, future and unknowable events cannot all be considered as random and this puts another nail in the coffin that is the REH. ${ }^{10}$

\section{Behavioural Finance: The Way Forward?}

The financial crisis has served to point up the weaknesses in the central propositions underlying the NNS model, and in particular the DSGE one used by the Federal Reserve and many other central banks, including the REH and the stronger versions of the EMH. While it is easy to criticise the failings of that model and it may remain as a benchmark from which new departures are made, deciding what to put in its place is rather more difficult. Certainly the crisis demonstrated the impotency of monetary policy and there remains considerable disagreement about the efficacy of fiscal policy. The crisis also highlighted the failure to incorporate financial markets and institutions into the formal models of macroeconomics. For far too many economists, finance was simply a veil that obscured the real economy from view (Mehrling, 2000).

An early attempt to model bounded rationality was Kahneman and Tversky's (1979) prospect theory that examines decision-making under uncertainty using psychology to derive the now famous S-shaped 'value function'. With changes in well-being on the $\mathrm{x}$ axis (rather than levels, because individuals respond to changes in their environment) and

\footnotetext{
${ }^{9}$ Chen (2010) argues that these liberalised relationships merely conceal complex non-linear relationships that should be analysed using complexity analysis.

${ }^{10}$ North (1999) provides an economic historian's view of non-ergodicity.
} 
happiness on the y axis, the function shows diminishing sensitivity to gains and losses in happiness. The function shows 'loss aversion', however, with the loss function steeper than the gains function. The theory can be operationalised by determining how to frame the choices that face individuals and, secondly, by examining the effect of bounded 'memories' (Thaler, 2000). This refers to the observation that memory can be selective making it difficult to distinguish between bad decisions and bad outcomes

Given the failure of DSGE models some economists have turned to behavioural economics that takes account of individual's emotions, cognitive errors and any other psychological factors that can have an impact on their decisions. Thaler (1997), in characterising Irving Fisher as pioneer of behavioural economics, defines it as having three characteristics. First, there is rational choice, secondly, an analysis of actual behaviour through collecting and processing data and thirdly, the use of the second feature to "explain and understand the ways of in which rational theories fail to describe the world we live in (p.439)". Financial markets should be viewed within an evolutionary framework where markets, policy instruments, institutions and investors interact dynamically in Darwinian (evolutionary) fashion. Financial agents compete and adapt, but this does not occur in any optimal way, but rather like Schumpeter's entrepreneurs adapt under the destructive powers of capitalism. Instead of maximising utility under RE, individuals seek to maximise their survival. Behaviour evolves through natural selection and what Simon (1955) calls 'satisficing' occurs when individual choices are deemed "satisfactory" through a process of trail and error, rather than though "optimising" behaviour. If the environment changes, then behaviour is adapted through a combination of competition, cooperation, market-making behaviour, general equilibrium and disequilibrium dynamics.

The Adaptive Markets Hypothesis (AMH) that encompasses this approach argues that prices reflect information gained from environmental conditions and the relevant market participants, e.g. market-makers, hedge-fund managers and investors. Financial markets, it is argued, would be more efficient the greater the number of participants and the higher the level of competition. Thus, Lo (2007) argues that "under the AMH, investment strategies undergo cycles of profitability and loss in response to changing business conditions, the number of competitors entering and exiting the industry, and the type and magnitude of profit opportunities available (pp.18-19)". 
In addition, the new sub-discipline of neuroeconomics finds compatibility between rational decision-making and emotion. Lo and Repin (2002) show that "physiological variables associated with the autonomic nervous system are highly correlated with market events even for highly experienced professional securities traders". And they go on to say "the ordinary degree of competitiveness of the global financial markets and the outsized rewards that accrue to the 'fittest' traders suggests that Darwinian selection - 'survival of the richest', to be precise - is at work in determining the typical profile of the successful trader". The authors conclude that even though behavioural economics is still in its infancy, it appears to be able to reconcile the contradictions between the EMH and behavioural reality. Thus the relationship between risk and reward is probably unstable through time depending on individual preferences and institutional factors such as prudential regulation and taxes. The implication of this, in contrast to the view of the $\mathrm{EMH}$, is that the equity risk premium is time-varying and path-dependent. Another important conclusion is that "of the three fundamental components of any market equilibrium - prices, probabilities and preferences - preferences are clearly the most fundamental and the least understood", so that this remains a pressing area for new research.

One recent attempt to find a new synthesis with behavioural economics was the meeting in 2010 at Virginia (US) of economists and computer scientists from the Federal Reserve, the Bank of England and various policy groups where 'agent-based models' (ABM) were explored. Agents (whether traders, firms or households) are assumed not to be representative of the whole population following some sort of ergodic process. Instead, individual agents are assigned behavioural rules where prices might be based on economic fundamentals, but where empirical evidence based on extrapolating past trends can provide equally valid rules. Here, if agents can interact directly and ignore pricing, then herd behaviour based on majority opinion becomes highly plausible. Computer simulations can then be used under different institutional rules to determine what the outcomes of herd behaviour are and these are found to exhibit large fluctuations and even crashes to be the norm through feedback mechanisms: equilibrium becomes the exception rather than the norm in this process. If these new $\mathrm{ABM}$ were mathematised then they would not be linear and the outcomes are not systematically related to the causes.

Three papers were particularly inspiring, showing how excessive debt emerges from rising house prices; falling interest rates and easy credit lead to debt cycles based on 
procyclical leveraging that causes Minsky-type instability and, finally, the interdependencies created by the growing complexity of financial instruments like CDOs and CDSs. In ABM the interactions between different sectors of the economy are equally as important as those between economic individual agents.

In this brief resume of some promising field for future research, one final important issue is the virtual universal opposition to market regulation with the free-market ideology that goes with the NNS. Thus, market failures are given less attention than they deserve including externalities, public goods, imperfect competition, asymmetric information combined with adverse selection, and moral hazard. The free market focus saw the deregulation of financial markets across the developed world including explicit or implicit removal of Glass-Steagall-type legislation. Behavioural economics in the view of McDonald (2009) can provide an explanation for the 2007 crisis on a number of counts and draw policy implications from them.

First, there is present bias or hyperbolic discounting, whereby the present is valued more highly than the future so that individuals may come to regret the decisions they made earlier: their behaviour is time-inconsistent. Secondly, the self-serving bias which means that assets are frequently priced above their fundamental value creating a bubble, but investors believe that they can sell before the market falls, but subsequently exactly the same errors are made: they are quintessential 'plungers' in Tobin's terms. Thirdly, new mathematical models were developed to calculate the risk associated with particular assets, but extraordinarily these ignored the risk that house prices would fall despite knowledge of the cyclical nature of house prices. Akerlof and Shiller (2009) explain this by invoking the concept of the "new era": in this new era falling asset prices were a thing of the past. Fourthly, the same authors argue that individuals over estimate the value of the increase in asset prices like house prices - the longer they have owned the house the larger the gain appears to be and the larger the loans they secure against the house. This is money illusion. Fifthly, agents also compare the rate of return with an unrealistic benchmark rate and because of 'loss aversion' take excessive risks. Recent low returns have lead to the search for higher yields and greater risk-taking. Finally, sixthly herding would exaggerate all of these tendencies - for example, taking on a subprime mortgage because others are doing so. 
McDonald's point is that these facets of the subprime financial crisis provide a convincing argument for regulation on the basis that individuals need to be protected from their own decisions and to be persuaded to take a longer view. This is in contrast with the NNS model that assumes individuals seek their own self-interest. Given the abject failure of government regulation what insights might behavioural economics offer? The answer is 'libertarian paternalism' as a default. Akerlof and Shiller (2009) offer one example, where the balance on a mortgage is adjusted according to changes in contiguous house prices so that the risk from changes in house prices would be shared between the borrower and the lender. More generally, regulation would need to respond to rising markets and the most obvious example is countercyclical capital requirements for banks. They would need to hold more capital in a period of boom and lend less and hold less capital in a recession and lend more. This accords with Minsky's view and will be part of Basel III. Any regulation, of course, must be taken into account the costs and the benefits.

\section{Conclusions}

Alan Greenspan conceded before Congress on October $23^{\text {rd }} 2008$ that "the modern risk paradigm [based on an ergodic view of the world] had held sway for decades. The whole intellectual edifice, however, has collapsed". This article has shown that macroeconomics had travelled a long way from the non-ergodic world of Keynes to its very antithesis in the REH and EMH, but that the subject is now moving back again. The way forward, therefore, may be to include the insights of behavioural economics. These economists also believe that in a non-ergodic world government policy interventions to shape institutions are necessary to improve the economic performance of markets by a system of floors and ceilings (Davidson, 1882-3). In a review of the subject, Akerlof (2001) has argued that 'in the spirit of Keynes' General Theory, behavioural macroeconomists are rebuilding the microfoundations that were sacked by the New Classical economists (pp.367-8)".

Frydman and Goldberg (2007, 2008 and 2010) have attempted to provide an alternative approach to the REH, although based on a microeconomic (or individualistic) approach to macroeconomics. They call this the Conditional Expectations Hypothesis. Under what they term "Imperfect Knowledge Economics", the formation of forecasts or expectations is subject to learning and is contextual and subject to change. They develop a theory where learning occurs and there are qualitative constraints, so that there is no unique set 
of expectations. For example, bulls and bears can be modelled so that their expectations about the possibility of a price changes move in different directions. There is not space to discuss this approach further, but it is another possibility for developing a formalisation of Keynesian conventional expectations.

\section{References}

Akerlof, G. A. (2001), "Behavioural Macroeconomics and Macroeconomic Behaviour", Prize Lecture, December $8^{\text {th }}$.

Akerlof, G. and Shiller, R. J. (2009), Animal Spirits: How Human Psychology Drives the Economy, and Why it Matters for Global Capitalism, Princeton: Princeton University Press.

Allington, N.F.B., McCombie, J.S.L. and Halford, M. (2010), "The Taylor Rule and European Monetary Policy, 1999-2009", Cambridge Centre for Economic and Public Policy, University of Cambridge, mimeo.

Arestis, P (2009), "New Consensus Macroeconomics and Keynesian Critique", in E Hein, T. Niechoji and E. Stockhammer (eds.), Macroeconomic Policies on Shaky Foundations: Wither Mainstream Macroeconomics? Metropolois-Verlage, Marburg.

Bernanke, B.S. (2010), "Monetary Policy and the Housing Bubble", paper presented at the Annual Meeting of the American Economic Association at Atlanta, Georgia, $3^{\text {rd }}$ January.

Bernanke, B.S. and Blinder, A.S. (1988), "Credit, Money, and Aggregate Demand", American Economic Review Papers and Proceedings, Vol. 78, No. 2, pp.435-439.

Bernanke, B.S. and Lown, C.S. (1991), "The Credit Crunch", Brookings Papers on Economic Activity, Vol. 2, pp.205-239.

Blanchard, O. (2009), "The Crisis: Basic Mechanisms and Appropriate Policies", IMF Working Papers 09/80, Washington: International Monetary Fund.

Blanchflower, D. (2009), "The Future of Monetary Policy”, lecture given at Cardiff University, $24^{\text {th }}$ March.

Brunnermeier, M. (2009), "Deciphering the Liquidity and Credit Crunch, 2007-2008", Journal of Economic Perspectives, Vol. 23, No.1, pp.77-100.

Buiter, W. (2009), “The Unfortunate Uselessness Of Most 'State Of The Art' Academic Monetary Economics", Financial Times, March $3^{\text {rd }}$

http://blogs.ft.com/maverecon/2009/03/the-unfortunate-uselessness-of-most-state-of-theart-academic-monetary-economics/ (accessed 19/11/10).

Chen, P. (2010), "Evolutionary Economic Dynamics. Persistent Cycles, Disruptive Technology, and the Trade-off between Stability and Complexity" in Chen, P. Economic Complexity and Equilibrium Illusion. Essays on Market Instability and Macro Vitality, Abingdon: Routledge. 
Cochrane, J. H. (2009), "How did Paul Krugman get it so Wrong?", September $16^{\text {th }}$ at http://faculty.chicagobooth.edu/john.cochrane/research/Papers/krugman_response.htm (accessed 12 November 2010)

Coval, J. D., Jurek, J. and Stafford, E. (2008), "The Economics of Structured Finance", Harvard Business School, Working Paper, 09-060.

Davidson, P. (1982-83), "Rational Expectations: A Fallacious Foundation for Studying Crucial Decision-Making Processes", Journal of Post Keynesian Economics, Vol. V, No. 2 (Winter), pp.182-198.

Davidson, P. (2008), "Is The Current Financial Distress Caused by the Subprime Mortgage Crisis a Minsky Moment? Or Is It the Result of Attempting to Securitize Illiquid Noncommercial Mortgage Loans?", Journal of Post Keynesian Economics, Vol. 30, No. 4, pp.669-676.

Dokko, J., Doyle, B., Kiley, M.T., Kim, J., Sherlund, S., Sim, J. and Van Den Heuval, S. (2009), "Monetary Policy and the Housing Bubble, Finance and Economics Discussion Series 2009-49, Washington, Board of Governors of the Federal System, December.

Fama, E. F. (2010), "Rational Irrationality. Interview with Eugene Fama" The New Yorker, January $13^{\text {th }}$.

Fama, E. F. (1965), "The Behaviour of Stock-Market Prices", Journal of Business, Vol. 38, No. 1, pp.34-105.

Felipe, J. and McCombie, J.S.L. (2005), "How Sound are the Foundations of the Aggregate Production Function?," Eastern Economic Journal, Vol. 31, No. 3, pp.467488.

Fisher, F. M. (1992), Aggregation. Aggregate Production Functions and Related Topic, (Monz, J., ed.), London: Harvester Wheatsheaf.

Frydman, R. and Goldberg, M.D. (2008), "Macroeconomic Theory for a World of Imperfect Knowledge", Centre on Capitalism and Society at Columbia University, Working Paper, No.24, May.

Frydman, R. and Goldberg, M.D. (2010), "Efficient Markets: Fictions and Reality", paper given to the Institute for New Economic Thinking, Cambridge, April.

Goodfriend, M. (2004), "Monetary Policy in the New Neoclassical Synthesis: A Primer", Economic Quarterly, Federal Reserve Bank of Richmond, Summer, pp.21-45.

Goodfriend, M. (2007), "How the World Achieved Consensus on Monetary Policy," Journal of Economic Perspectives, Vol. 21, No. 4, pp.47-68, Fall.

Goodhart, C. (2010), "Comments on "Credit Frictions and Optimal monetary policy" by Curdia and Woodford", at http://www.bis.org/events/conf080626/goodhart.pdf (accessed 12th November)

Hendry, D. F. and Mizon, G. (2010) "On the Mathematical Basis of Inter-temporal Optimization", Economics Series Working Papers 497, University of Oxford, Department of Economics. 
Hicks, J. (1979), "IS-LM: An Explanation”, Journal of Post Keynesian Economics, Vol. 3, pp.139-154.

Hume, D. (1888), Hume's Treatise of Human Nature, ed. L. A. Selby Bigge, Oxford: Clarendon Press. Originally published 1739-1740.

Kahneman, D. and Tversky, A. (1979), "Prospect Theory: An Analysis of decision Under Risk", Econometrica, Vol. 47, No. 2, pp.263-91.

Keynes, J. M. (1936), The General Theory of Employment, Interest and Money, London: Macmillan.

Keynes, J. M. (1937), “The General Theory of Employment”, Quarterly Journal of Economics, Vol. 51, pp.209-223.

Kirman, A. (1992), "Whom or What Does the Representative Individual Represent?", Journal of Economic Perspectives, Vol. 6, No.2, pp.117-136.

Knight, F. H. (1921), Risk, Uncertainty, and Profit, Hart, Schaffner and Marx Prize Essays, No. 31, Boston and New York: Houghton Mifflin.

Krugman, P. (2009), "How Did Economists Get It So Wrong?", New York Times, $2^{\text {nd }}$ September. http://www.nytimes.com/2009/09/06/magazine/06Economic-t.html (accessed 19/11/10).

Leamer, E. E. (2010), "Tantalus on the Road to Asymptopia", Journal of Economic Perspectives, Vol. 24, No. 2, pp.31-46.

Lo, A. W. (2007), "Efficient Markets Hypothesis", in L. Blume and S. Durlauf, eds. The New Palgrave: A Dictionary of Economics, Second Edition, New York: Palgrave MacMillan.

Lo, A. W. and Repin, D. (2002), "The Psychophysiology of Real-Time Financial Risk Processing", Journal of Cognitive Neuroscience, Vol. 14, pp.323-39.

Lucas, R.E. (1978), “Unemployment Policy”, American Economic Review Papers and Proceedings, Vol. 68, pp.353-357.

Lucas, R.E. (2009), "In Defence of the Dismal Science", The Economist, August $6^{\text {th }}$. Available at http://www.princeton.edu/ markus/misc/Economist_Lucas_roundtable/Lucas_article_Th e_Economist.pdf (accessed 22/11/10)

Mehrling, P. (2000), "What is Monetary Economics About?", Barnard College, Columbia University mimeo.

Meyer, L.H. (2001), “Does Money Matter?”, Review, Federal Reserve Bank of St. Louis, September/ October, pp.1-15. 
McCombie, J.S.L. (2010), “The Thatcher Monetarist Experiment, 1979-85: An Assessment" in G. Fontana, J.S.L. McCombie, and M.C. Sawyer, Macroeconomics, Finance and Money, Basingstoke: Macmillan.

McCombie, J.S.L. and Pike, M. (2010), "The End of the Consensus in Macroeconomic Theory? A Methodological Inquiry", Cambridge Centre for Economic and Public Policy, University of Cambridge.

McDonald, I. M. (2009), "The Global Financial Crisis and Behavioural Economics", Economics Papers, Vol 28, No. 3, pp.249-54.

Mian, A. R. and Sufi, A. (2008), "The Consequences of Mortgage Credit Expansion: Evidence from the U.S. Mortgage Default Crisis", Available at SSRN: http://ssrn.com/abstract=1072304 (Accessed 12 November 2010).

North, D. C. (1999), "Dealing with a Non-Ergodic World: Institutional Economics, Property Rights, and the Global Environment", Duke Environmental Law and Policy Forum, Vol. 10, No. 1, pp.1-12.

Roubini, N. (2006), Speech to the IMF on the impending financial crisis.

Roubini, N. and Mihm, S. (2010), Crisis Economics. A Crash Course in the Future of Finance, London: Allen Lane Press.

Rajan, R. G. (2005), "Has Financial Development Made the World Riskier?", Proceedings, Federal Reserve Bank of Kansas City, August, pp.313-369.

Rajan, R. G. (2010), Fault Lines. How Hidden Fractures Still Threaten the World Economy, Princeton: Princeton University Press.

Samuelson, P. A. (1965), "Proof that Properly Anticipated Prices Fluctuate Randomly," Industrial Management Review, Vol. 6, pp.41-49.

Samuelson, P. A. (2004), "Where Ricardo and Mill Rebut and Confirm Arguments of Mainstream Economists Supporting Globalisation", Journal of Economic Perspectives, Vol. 18, No. 3, pp.135-146.

Simon, H. (1955), “A Behavioural Model of Rational Choice”, Quarterly Journal of Economics, Vol. 69, No. pp.99-118.

Solow, R.M. (2008), "Comment: The State of Macroeconomics", Journal of Economic Perspectives, Vol. 22, No. 1, pp.243-249.

Summers, L. (1991), "The Scientific Illusion in Empirical Macroeconomics." Scandinavian Journal of Economics, Vol. 93, No. 1, pp.129-148.

Taylor, J. B. (1993), "Discretion versus Policy Rules in Practice", Carnegie-Rochester Series on Public Policy, Vol. 39, pp.195-214.

Taylor, J. B. (2007), "Housing and Monetary Policy”, NBER Working Paper, No. 13682. 
Taylor, J. B. (2009), Getting Off Track. How Government Actions and Interventions Caused, Prolonged and Worsened the Financial Crisis, Stanford: Hoover Institution Press.

Thaler, R. H. (1997), "Irving Fisher: Modern Behavioural Economist", Journal of Economic Perspectives, Vol. 17, No. 4, pp.191-202.

Thaler, R. H. (2000), "From Homo Economicus to Homo Sapiens", Journal of Economic Perspectives, Vol. 14, No. 1, pp.133-141.

Wenli, L., White, M. J. and Zhu, N. (2010), "Did Bankruptcy cause Mortgage Defaults to Rise?", Federal Reserve Bank of Philadelphia, mimeo. 